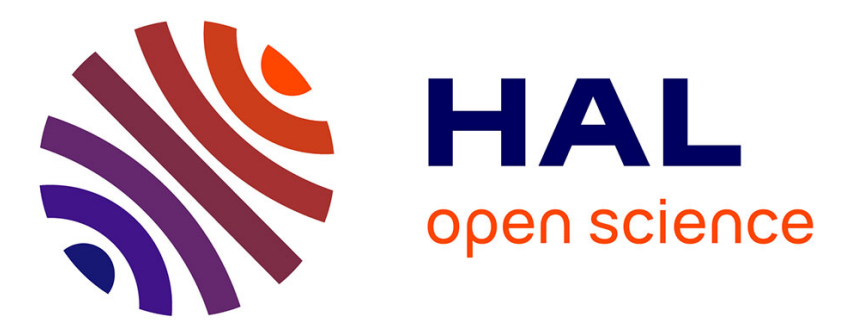

\title{
Extraction and Preparation of Listeria monocytogenes Subproteomes for Mass Spectrometry Analysis
}

\author{
Tiago Santos, Michel Hébraud
}

\section{To cite this version:}

Tiago Santos, Michel Hébraud. Extraction and Preparation of Listeria monocytogenes Subproteomes for Mass Spectrometry Analysis. Methods in molecular biology (Clifton, N.J.), 2220, 2021, pp.137-153, 2021, 10.1007/978-1-0716-0982-8_11. hal-02957323

\section{HAL Id: hal-02957323 \\ https://hal.inrae.fr/hal-02957323}

Submitted on 5 Oct 2020

HAL is a multi-disciplinary open access archive for the deposit and dissemination of scientific research documents, whether they are published or not. The documents may come from teaching and research institutions in France or abroad, or from public or private research centers.
L'archive ouverte pluridisciplinaire HAL, est destinée au dépôt et à la diffusion de documents scientifiques de niveau recherche, publiés ou non, émanant des établissements d'enseignement et de recherche français ou étrangers, des laboratoires publics ou privés. 


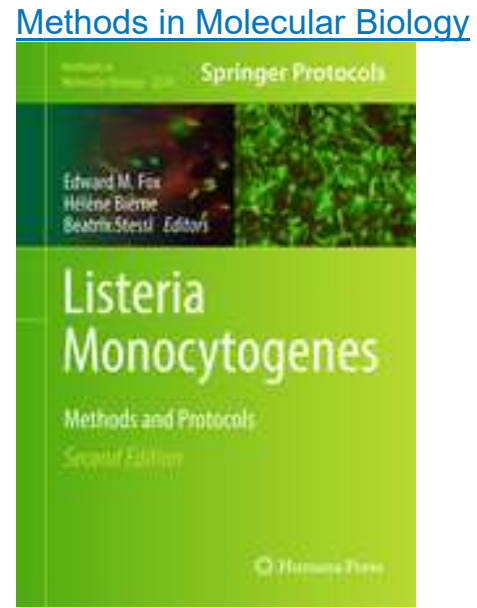

(C) 2021

\title{
Listeria Monocytogenes
}

\section{Methods and Protocols}

\author{
Editors: Fox, Edward M., Bierne, Hélène, Stessl, Beatrix (Eds.)
}

\section{Chapter 11}

\section{Extraction and Preparation of Listeria monocytogenes Subproteomes for Mass Spectrometry Analysis}

\section{TiagoSantos 1}

MichelHébraud 1,2 $\square$ Email michel.hebraud@inra.fr

1 Université Clermont Auvergne (UCA), Institut National de Recherche pour l'Agriculture, l'Alimentation et l'Environnement (INRAE) Unité Mixte de Recherche (UMR) Microbiologie Environnement Digestif Santé (MEDiS) Saint-Genès Champanelle France 2Institut National de Recherche pour l'Agriculture, l'Alimentation et l'Environnement (INRAE) Metabolomic and Proteomic Exploration Facility (PFEM) Saint-Genès Champanelle France

\section{Abstract}

Proteomics has become an essential tool to answer biologists' questions. For bacteriologists, the proteome of bacteria is much less complex than that of eukaryotic organisms. However, not all the different cell "compartments" are easily accessible, and the analysis of cell envelope proteins is particularly challenging. For the Gram-positive bacterium Listeria monocytogenes, one of the main foodborne pathogen microorganisms, the study of surface proteins is crucial to better understand the mechanisms of pathogenicity, as well as adaptation/resistance to and persistence in hostile environments. The evolution of proteomic techniques, and particularly the possibility of separating and analyzing complex protein samples by off-gel (LC-MS/MS) versus in-gel (twodimensional electrophoresis) approach, has opened the doors to new extraction and preparation methods to target the different subproteomes. Here, we describe three procedures to prepare and analyze intracellular, exocellular, and cell surface proteins: (1) the cell fractionation, based on cell broken and separation of protein subfractions by differential centrifugation; (2) the biotinylation, based on the labeling of cell surface proteins and their selective extraction; and (3) the enzymatic shaving by the action of trypsin on intact cells. These complementary methods allow to encompass all L. monocytogenes subproteomes for general profiling or target studies and could be applicable to other Gram-positive bacteria.

Key words

Subproteomic approaches; Proteosurfaceome; Fractionation method; Biotinylation; Trypsin shaving 


\section{Introduction}

The bacterial cell envelope constitutes a physicochemical barrier but also a place for exchanges and communication between the intracellular content and the external environment. In Grampositive bacteria, it consists of a cell wall and then a single cytoplasmic membrane from the outside to the inside of the cell, which also refers to these bacteria as monoderms as opposed to Gram-negative bacteria called diderms because of the presence of two internal and external membranes separated by a periplasmic space [12]. In Listeria monocytogenes, a foodborne pathogenic monoderm bacterium, the cell envelope is of particular interest, particularly because of its role in pathogenicity, and has been the subject of numerous descriptions [3456]. The cell wall is formed by the peptidoglycan ( $N$-acetylglucosamine and $N$-acetylmuramic acid) in which are anchored teichoic acids, polysaccharides, and proteins. These proteins may be covalently bound to the peptidoglycan by a C-terminal LPXTG motif or non-covalently by different motifs or domains to the peptidoglycan or polysaccharides. The membrane surrounding the cytoplasm consists of a phospholipid bilayer in which proteins are embedded, representing 55-60\% of the listerial membrane [7] and to a lesser extent some carbohydrates. The cytoplasmic proteins are either anchored by one or more transmembrane domains, which is the case for the so-called proteins "integral membrane proteins", or covalently attached to the acyl group of two fatty acids, like lipoproteins [28]. In addition to these proteins, the cellular envelope is the site of secretion systems and the anchor point for appendages (pili, flagella), some of which form complex protein structures [910]. The term surfaceome encompasses all the molecules that make up this cellular envelope, while the proteosurfaceome refers only to all proteins. Many important, even essential functions are attributed to the proteosurfaceome such as molecule transport, growth, adhesion to biotic or abiotic substrates, virulence and invasion process, perception, and adaptation to the environment. L. monocytogenes also includes flagella and six known secretion systems [9]. As a result, the proteosurfaceome is attracting considerable interest in different areas of research.

In addition to the proteosurfaceome, two other subproteomes can be considered in bacteria: (1) the exoproteome, consisting of the proteins present in the extracellular medium [111], and the intracellular proteome consisting of cytoplasmic proteins. The extraction and preparation of samples from these two subproteomes, already described in detail [12], are relatively easy compared to the proteosurfaceome samples. Indeed, for surfaceome proteins, given their location and especially their anchors in the membrane or cell wall, their low solubility, and often low abundance, it is a real challenge to extract and, consequently, to analyze them as a whole. Because of their interest, bacterial cell envelope proteins have undergone numerous methodological developments to extract and identify them as exhaustively as possible [131415]. For Grampositive bacteria [16] and more particularly L. monocytogenes, several protocols have been tested [171819] and sometimes compared for planktonic cells [20] or sessile cells forming biofilm [2122]. In a global way, it is not realistic to consider a single method to study the entire proteosurfaceome, and, on the other hand, the extracts obtained by any method are significantly contaminated with cytosoluble proteins, even when all precautions are taken to avoid cell lysis. The choice of a method makes it possible to target the type of proteins that will be preferentially extracted, such as shaving for covalently or non-covalently attached cell wall proteins, biotin labeling for lipoproteins, or the SDS/trypsin approach for LPXTG cell wall-anchored proteins [18]. This means that a multi-approach strategy, taking advantage of their complementarity, is necessary to best explore the proteosurfaceome. To this end, the protocols presented here, which have been developed on L. monocytogenes biofilms cells [22], are complementary to analyze the different subproteomes of the pathogen and tackle the difficult challenge of proteosurfaceome exploration. They include (1) the classical cell fractionation approach to separate the intracellular, exocellular, cell wall, and membrane subproteomes, (2) biotin labeling and selective extraction of labeled surface proteins, and (3) trypsin shaving of proteins on the surface of intact cells. The different approaches are described until the preparation of the samples for LC-MS-MS analysis (shotgun proteomics). These protocols can be applied to planktonic cells of L. monocytogenes but also, with sometimes minor modifications, to other Gram-positive bacteria.

\section{Materials}


All solutions are prepared using ultrapure water (obtained by purifying deionized water to attain $18 \mathrm{M} \Omega \mathrm{cm}$ at $25^{\circ} \mathrm{C}$ ) and analytical grade reagents specifically dedicated to proteomics and stored apart from other laboratory chemicals at room temperature (unless indicated otherwise). Wear protective laboratory clothing such as powder-free gloves, closed overalls, and hair nets without cotton (e.g., in polypropylene) to protect yourself and to prevent protein contamination, particularly from skin and hair keratins. All work with living cells of Listeria monocytogenes must be performed in a class II biosafety cabinet.

\subsection{Recovering All Subfractions by Cell Fractionation Approach}

1.TE buffer: $20 \mathrm{mM}$ Tris-HCl, pH 7.5, $5 \mathrm{mM}$ EDTA, $5 \mathrm{mM} \mathrm{MgCl}$. Weigh $242 \mathrm{mg}$ Tris, $186 \mathrm{mg}$ EDTA, and $48 \mathrm{mg} \mathrm{MgCl}_{2}$, and transfer in a graduated glass beaker containing $90 \mathrm{~mL}$ of water. Mix under magnetic stirring and adjust the $\mathrm{pH}$ with $\mathrm{HCl}$. Remove the magnetic stir bar and make up to $100 \mathrm{~mL}$. Store at $4{ }^{\circ} \mathrm{C}$. Prepare the same TE buffer but adjusting the final $\mathrm{pH}$ to 9.0.

2.Phenylmethylsulfonyl fluoride (PMSF) solution: $20 \mathrm{mM}$ in ethanol 100\%. Weigh $34.84 \mathrm{mg}$ and dissolve in $10 \mathrm{~mL}$ pure ethanol (see Note 1). Store in the dark at $-20{ }^{\circ} \mathrm{C}$.

3.Sodium deoxycholate solution: $2 \%$ solution in water. Weigh $200 \mathrm{mg}$ NA deoxycholate and dissolve in $10 \mathrm{~mL}$ of water (see Note 2).

4.Trichloroacetic acid (TCA) solution: $50 \%$ TCA in water. Weigh $50 \mathrm{~g}$ TCA and dissolve in $80 \mathrm{~mL}$ of water by magnetic stirring. Remove the magnetic stir bar and make up to $100 \mathrm{~mL}$ with water (see Note 3 ).

5.Tris buffer: $40 \mathrm{mM}$ Tris-HCl, $\mathrm{pH} 8.5$. Weigh $482 \mathrm{mg}$ Tris, transfer in a graduated glass beaker containing $95 \mathrm{~mL}$ of water. Mix under magnetic stirring and adjust the $\mathrm{pH}$ with $\mathrm{HCl}$. Remove the magnetic stir bar and make up to $100 \mathrm{~mL}$. Store at $4{ }^{\circ} \mathrm{C}$.

6.SDS buffer: $1 \%$ SDS, 0.1 M DTT, 20 mM Tris-HCl, pH 7.6. Weigh 1 g SDS, 1.542 g DTT, and $0.315 \mathrm{~g}$ Tris, and transfer in a graduated glass beaker containing $90 \mathrm{~mL}$ of water. Mix under magnetic stirring and adjust the $\mathrm{pH}$ with $\mathrm{HCl}$. Remove the magnetic stir bar and make up to $100 \mathrm{~mL}$. Store at $4{ }^{\circ} \mathrm{C}$.

\subsection{Proteosurfaceome-Targeted Approaches. Biotinylation of Cell Surface Proteins}

1.PBS buffer: $0.01 \mathrm{M}$ PBS pH 8. Weigh $276 \mathrm{mg} \mathrm{NaH} \mathrm{PO}_{4} \cdot \mathrm{H}_{2} \mathrm{O}$, and transfer in a graduated glass beaker containing $10 \mathrm{~mL}$ of water (solution A), and mix under magnetic stirring. Weigh $5.365 \mathrm{~g}$ $\mathrm{NaH}_{2} \mathrm{PO}_{4} \cdot 7 \mathrm{H}_{2} \mathrm{O}$, and transfer in a graduated glass beaker containing $100 \mathrm{~mL}$ of water (solution $\mathrm{B}$ ), and mix under magnetic stirring. Weigh $7400 \mathrm{mg} \mathrm{NaCl}$, and transfer in a graduated glass beaker containing $2.6 \mathrm{~mL}$ solution A, $47.35 \mathrm{~mL}$ solution $\mathrm{B}$, and $1000 \mathrm{~mL}$ of water. Mix under magnetic stirring. Filter the solution through a $0.2 \mu \mathrm{m}$ filter. Store at $4{ }^{\circ} \mathrm{C}$.

2.PMSF buffer: $0.01 \mathrm{M}$ PBS pH 8, $1 \mathrm{mM}$ PMSF (see Note 1). Prepare $100 \mathrm{mM}$ PMSF. Weigh $174 \mathrm{mg}$, and transfer in a graduated glass beaker containing $10 \mathrm{~mL}$ of ethanol absolute. Mix under magnetic stirring. Dilute $1 / 100$ of $100 \mathrm{mM}$ PMSF in $0.01 \mathrm{M}$ PBS pH 8. Mix under magnetic stirring. Store in the dark at $-20{ }^{\circ} \mathrm{C}$.

3.Biotin buffer: $16 \mathrm{mM}$ sulfo-NHS-SS-biotin (see Note 4), $0.01 \mathrm{M}$ PBS pH 8. Weigh $1 \mathrm{mg}$ sulfoNHS-SS-biotin, and transfer in a sterile Eppendorf containing $100 \mu 10.01 \mathrm{M}$ PBS pH 8.

4.Triton buffer: $1 \%(\mathrm{v} / \mathrm{v})$ Triton X100, 0.01 M PBS pH 8, $1 \mathrm{mM}$ PMSF (see Note 5). Transfer $20 \mu \mathrm{L}$ Triton X100 in a graduated glass containing $1.96 \mathrm{~mL} 0.01 \mathrm{M}$ PBS pH 8 and $20 \mu \mathrm{L} 100 \mathrm{mM}$ PMSF. Store at $4{ }^{\circ} \mathrm{C}$.

5.Glycine buffer: $0.01 \mathrm{M}$ PBS pH 8, $500 \mathrm{mM}$ glycine. Weigh $3.754 \mathrm{~g}$ glycine, and transfer in a graduated glass beaker containing $100 \mathrm{~mL} 0.01 \mathrm{M} \mathrm{PBS} \mathrm{pH}$ 8. Mix under magnetic stirring. Store at $4{ }^{\circ} \mathrm{C}$.

6.NP-40 buffer: $1 \%(\mathrm{v} / \mathrm{v})$ NP-40, $0.01 \mathrm{M}$ PBS pH 8 (see Note 6). Transfer $1 \mathrm{~mL}$ NP-40 in a graduated glass beaker containing $99 \mathrm{~mL} 0.01 \mathrm{M}$ PBS pH 8. Mix under magnetic stirring. Store at $4{ }^{\circ} \mathrm{C}$.

7.Reducing buffer: $62.5 \mathrm{mM}$ Tris- $\mathrm{HCl} \mathrm{pH} 6.8,2 \%$ SDS, $20 \%$ glycerol, $50 \mathrm{mM}$ DTT, and 5\% $\beta-$ mercaptoethanol. Weigh $985 \mathrm{mg}$ Tris- $\mathrm{HCl} \mathrm{pH} 6.8,2 \mathrm{~g}$ SDS (see Note 7) and $771 \mathrm{mg}$ DTT 
(see Note 8), and transfer in a graduated glass beaker containing $20 \mathrm{~mL}$ glycerol, $5 \mathrm{~mL} \beta$ mercaptoethanol, and $65 \mathrm{~mL}$ of water. Mix under magnetic stirring and adjust the $\mathrm{pH}$ with $\mathrm{HCl}$. Remove the magnetic stir bar and make up to $100 \mathrm{~mL}$. Store in the dark at $-20{ }^{\circ} \mathrm{C}$.

\subsubsection{Trypsin Shaving of Cell Surface Proteins}

1.TBS buffer: $20 \mathrm{mM}$ Tris- $\mathrm{HCl} \mathrm{pH} 7.4,150 \mathrm{mM} \mathrm{NaCl}$. Weigh $1.575 \mathrm{~g}$ Tris and $4.4 \mathrm{~g} \mathrm{NaCl}$, and transfer in a graduated glass beaker containing $400 \mathrm{~mL}$ of water. Mix under magnetic stirring and adjust the $\mathrm{pH}$ with $\mathrm{HCl}$. Remove the magnetic stir bar and make up to $500 \mathrm{~mL}$. Store at $4{ }^{\circ} \mathrm{C}$.

2.Hydrolysis buffer: $20 \mathrm{mM}$ Tris- $\mathrm{HCl}, 150 \mathrm{mM} \mathrm{NaCl}, 10 \mathrm{mM} \mathrm{CaCl}{ }_{2} \cdot 6 \mathrm{H}_{2} \mathrm{O}, 1 \mathrm{M}$ L-arabinose, trypsin $0.5 \mu \mathrm{g} / \mathrm{mL}$. Weigh $315 \mathrm{mg}$ Tris, $880 \mathrm{mg} \mathrm{NaCl}, 220 \mathrm{mg} \mathrm{CaCl} \cdot 6 \mathrm{H}_{2} \mathrm{O}, 15 \mathrm{~g} \mathrm{~L}$-arabinose, and $100 \mathrm{mg}$ trypsin $(0.5 \mu \mathrm{g} / \mathrm{mL})$, and transfer in a graduated glass beaker containing $100 \mathrm{~mL}$ of water. Mix under magnetic stirring.

\subsection{SDS-Polyacrylamide Gel Electrophoresis (SDS-PAGE)}

\subsubsection{SDS-PAGE}

1.Tris buffer $\mathrm{pH}$ 6.8: $1 \mathrm{M}$ Tris- $\mathrm{HCl}, \mathrm{pH}$ 6.8. Weigh $315.2 \mathrm{~g}$ Tris; transfer in a graduated glass beaker containing $1.8 \mathrm{~L}$ of water. Mix under magnetic stirring and adjust the $\mathrm{pH}$ with $\mathrm{HCl}$. Remove the magnetic stir bar and make up to $2 \mathrm{~L}$. Store at $4{ }^{\circ} \mathrm{C}$.

2.Resolving gel buffer: $1.5 \mathrm{M}$ Tris- $\mathrm{HCl}, \mathrm{pH}$ 8.8. Weigh $472.8 \mathrm{~g}$ Tris; transfer in a graduated glass beaker containing $1.8 \mathrm{~L}$ of water. Mix under magnetic stirring and adjust the $\mathrm{pH}$ with $\mathrm{HCl}$. Remove the magnetic stir bar and make up to $2 \mathrm{~L}$. Store at $4{ }^{\circ} \mathrm{C}$.

3.Laemmli buffer $(2 \times): 125 \mathrm{mM}$ Tris-HCl, pH 6.8, 20\% glycerol, 2\% SDS, 5\% $\beta-$ mercaptoethanol, and bromophenol blue (a few grains to color the solution). Transfer $1.25 \mathrm{~mL}$ $1 \mathrm{M}$ Tris $-\mathrm{HCl}, \mathrm{pH} 6.8$, in a graduated glass beaker containing $2 \mathrm{~mL}$ glycerol, $4 \mathrm{~mL} \mathrm{10 \%} \mathrm{SDS,}$ $1 \mathrm{~mL} \beta$-mercaptoethanol, $1 \mathrm{~mL} 0.5 \%$ bromophenol blue, and $1.75 \mathrm{~mL}$ of water. Mix under magnetic stirring.

4.Acrylamide/ $N, N^{\prime}$-methylene-bis-acrylamide (cross-linker) solution. Use ready-to-use $40 \%$ acrylamide/bis solution $\left(37.5: 1 ; 2.6 \% \mathrm{C}\right.$, Bio-Rad, Hercules, CA, USA), and store at $4{ }^{\circ} \mathrm{C}$ in the dark.

5.SDS solution: $10 \%$ solution in water. Dissolve $10 \mathrm{~g}$ SDS in $60 \mathrm{~mL}$ water with gentle stirring to minimize the bubbles made by SDS. Complete with water to $100 \mathrm{~mL}$.

6.Ammonium persulfate: $10 \%$ solution in water. Weigh $200 \mathrm{mg}$ ammonium persulfate (see Note 9), and dissolve in a final volume of $2 \mathrm{~mL}$ of water. Store in the dark at $-20{ }^{\circ} \mathrm{C}$.

7.TEMED $\left(N, N, N^{\prime}, N^{\prime}\right.$-tetramethylethylenediamine). Ready-to-use solution, store at $4{ }^{\circ} \mathrm{C}$ in the dark (see Note 10).

8.Preparation of a $12.5 \%$ acrylamide resolving gel. For a final volume of $80 \mathrm{~mL}$ (necessary for 4 Bio-Rad's Mini-PROTEAN ${ }^{\circledast}$ Tetra cell $100 \mathrm{~mm}$ (length) $\times 80 \mathrm{~mm}$ (width) $\times 1 \mathrm{~mm}$ (thickness)

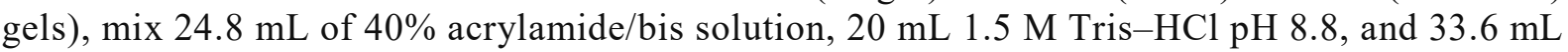
of water. Degas the solution under vacuum for $10 \mathrm{~min}$. Add $0.8 \mathrm{~mL}$ of $10 \%$ SDS solution, $0.4 \mathrm{~mL}$ of $10 \%$ ammonium persulfate solution, and $40 \mu \mathrm{L}$ of TEMED. Let the final solution well homogenize for $1 \mathrm{~min}$ by moderate stirring before loading the gel.

9.Preparation of a $4 \%$ acrylamide stacking gel. For a final volume of $20 \mathrm{~mL}$ (necessary for four Bio-Rad's Mini-PROTEAN ${ }^{\circledR}$ Tetra cell gels), mix $2 \mathrm{~mL}$ of $40 \%$ acrylamide/bis solution, $5 \mathrm{~mL}$ $0.5 \mathrm{M}$ Tris $-\mathrm{HCl} \mathrm{pH} \mathrm{8.8,} \mathrm{and} 12.8 \mathrm{~mL}$ of water. Degas the solution under vacuum for $10 \mathrm{~min}$. Add $0.2 \mathrm{~mL}$ of $10 \%$ SDS solution, $0.1 \mathrm{~mL}$ of $10 \%$ ammonium persulfate solution, and $20 \mu \mathrm{L}$ of TEMED. Let the final solution well homogenize for $1 \mathrm{~min}$ by moderate stirring before loading the gel.

10.SDS-PAGE running buffer: $25 \mathrm{mM}$ Tris-HCl, $\mathrm{pH} 8.3,0.192 \mathrm{M}$ glycine, $0.1 \%$ SDS. Prepare $10 \times$ stock buffer $(0.25 \mathrm{M}$ Tris- $\mathrm{HCl}, 1.92 \mathrm{M}$ glycine, $1 \% \mathrm{SDS})$. Weigh $30.3 \mathrm{~g}$ Tris and $144 \mathrm{~g}$ glycine; dissolve by magnetic stirring in a graduated glass beaker containing $900 \mathrm{~mL}$ of water. Add $10 \mathrm{~mL}$ of $10 \%$ SDS solution and complete to $1 \mathrm{~L}$ with water. Do not adjust the $\mathrm{pH}$ with acid 
or base. Store at room temperature (RT). Before use, dilute $100 \mathrm{~mL}$ of $10 \times$ stock buffer to $900 \mathrm{~mL}$ of water.

\subsubsection{Protein Staining and Band Treatment After Excision}

1.Fixing solution: $30 \%$ ethanol, $2 \%(\mathrm{v} / \mathrm{v})$ phosphoric acid in water. An $85 \%$ concentrated phosphoric acid is used. For $1 \mathrm{~L}$ fixing solution, add $20 \mathrm{~mL}$ of $85 \%$ phosphoric acid.

2.Washing solution: $2 \%(\mathrm{v} / \mathrm{v})$ phosphoric acid in water. An $85 \%$ concentrated phosphoric acid is used. For $1 \mathrm{~L}$ fixing solution, add $20 \mathrm{~mL}$ of $85 \%$ phosphoric acid.

3.Equilibration solution: $18 \%$ ethanol, $2 \%(\mathrm{v} / \mathrm{v})$ phosphoric acid, and 15\% ammonium persulfate in water. For $1 \mathrm{~L}$ of solution, place $500 \mathrm{~mL}$ of water in a flask with magnetic stirring. Add $20 \mathrm{~mL}$ of $85 \%$ phosphoric acid, then $150 \mathrm{~g}$ of ammonium sulfate. Allow to dissolve, transfer into a graduated cylinder, and adjust to $800 \mathrm{~mL}$ with water. Add $20 \mathrm{~mL}$ additional water, retransfer into the flask with stirring, and add $180 \mathrm{~mL}$ ethanol while stirring.

4.Coomassie brilliant blue G-250 (or colloidal Coomassie blue G-250) 2\% solution: dissolve $2 \mathrm{~g}$ of pure Coomassie brilliant blue G-250 in $100 \mathrm{~mL}$ of hot water with stirring. Wait about $30 \mathrm{~min}$ for complete dissolution.

5.Coloration solution: 1\% Coomassie brilliant blue G-250 2\% solution (see step 4) in equilibration solution (see step 3). For $1 \mathrm{~L}$ of solution, transfer $10 \mathrm{~mL}$ Coomassie brilliant blue G-250 2\% solution to $990 \mathrm{~mL}$ of equilibration solution in a flask with magnetic stirring.

6.Ammonium bicarbonate solution: $100 \mathrm{mM}$ ammonium bicarbonate. Weigh $791 \mathrm{mg}$ ammonium bicarbonate, and dissolve in a final volume of $100 \mathrm{~mL}$ of water. Mix under magnetic stirring. Remove the magnetic stir bar and store at $4{ }^{\circ} \mathrm{C}$.

7.Band gel destaining solutions after their excision: $25 \mathrm{mM}$ ammonium bicarbonate and $5 \% \mathrm{ACN}$ (acetonitrile), transfer $25 \mathrm{~mL}$ ammonium bicarbonate into a flask with $70 \mathrm{~mL}$ of water and $5 \mathrm{~mL}$ of ACN; $25 \mathrm{mM}$ ammonium bicarbonate and $50 \% \mathrm{ACN}$, transfer $25 \mathrm{~mL}$ ammonium bicarbonate into a flask with $25 \mathrm{~mL}$ of water and $50 \mathrm{~mL}$ of ACN. Store at $4{ }^{\circ} \mathrm{C}$.

8.Reduction solution: $10 \mathrm{mM}$ dithiothreitol (DTT), $100 \mathrm{mM}$ ammonium bicarbonate. Weight $1.54 \mathrm{mg}$ of DTT, and transfer into $10 \mathrm{~mL} 100 \mathrm{mM}$ ammonium bicarbonate. Store at $4{ }^{\circ} \mathrm{C}$.

9.Alkylation solution: $55 \mathrm{mM}$ iodoacetamide (see Note 11), $100 \mathrm{mM}$ ammonium bicarbonate. Weight $1.54 \mathrm{mg}$ of DTT and transfer into $10 \mathrm{~mL} 100 \mathrm{mM}$ ammonium bicarbonate. Store in the dark at $4{ }^{\circ} \mathrm{C}$.

10.Dehydration solution: $100 \%$ ACN.

11. Trypsin digestion solution: $25 \mathrm{mM}$ ammonium bicarbonate, $12.5 \mathrm{ng} / \mu \mathrm{L}$ trypsin solution. For 40 samples, add $48 \mu \mathrm{L}$ of this solution. Dilute $600 \mathrm{ng}$ sequencing-grade trypsin in $480 \mu \mathrm{L}$ $100 \mathrm{mM}$ ammonium bicarbonate and $1440 \mu \mathrm{L}$.

\section{Methods}

Carry out all procedures at room temperature (RT) unless otherwise specified. Wear protective laboratory clothing as specified above.

The growth conditions (inoculum, culture medium, temperature, $\mathrm{pH}$, agitation, etc.), the population, and the growth phase of the bacterial culture at the time of its recovery must be perfectly controlled and mastered in order to reproduce the same experience for biological replicates. This is the same for all the extraction and protein separation methodologies which must be optimized and standardized to carry out technical replicates from the protein extracts. On average, it is necessary to perform at least three (to five) biological replicates with two to four technical replicates for each protein extract to ensure good reproducibility and repeatability of results and to allow their validation by solid statistical analysis. Hereafter are described the methodologies to obtain different L. monocytogenes subproteomes (Fig. 1). 


\subsection{Cell Fractionation}
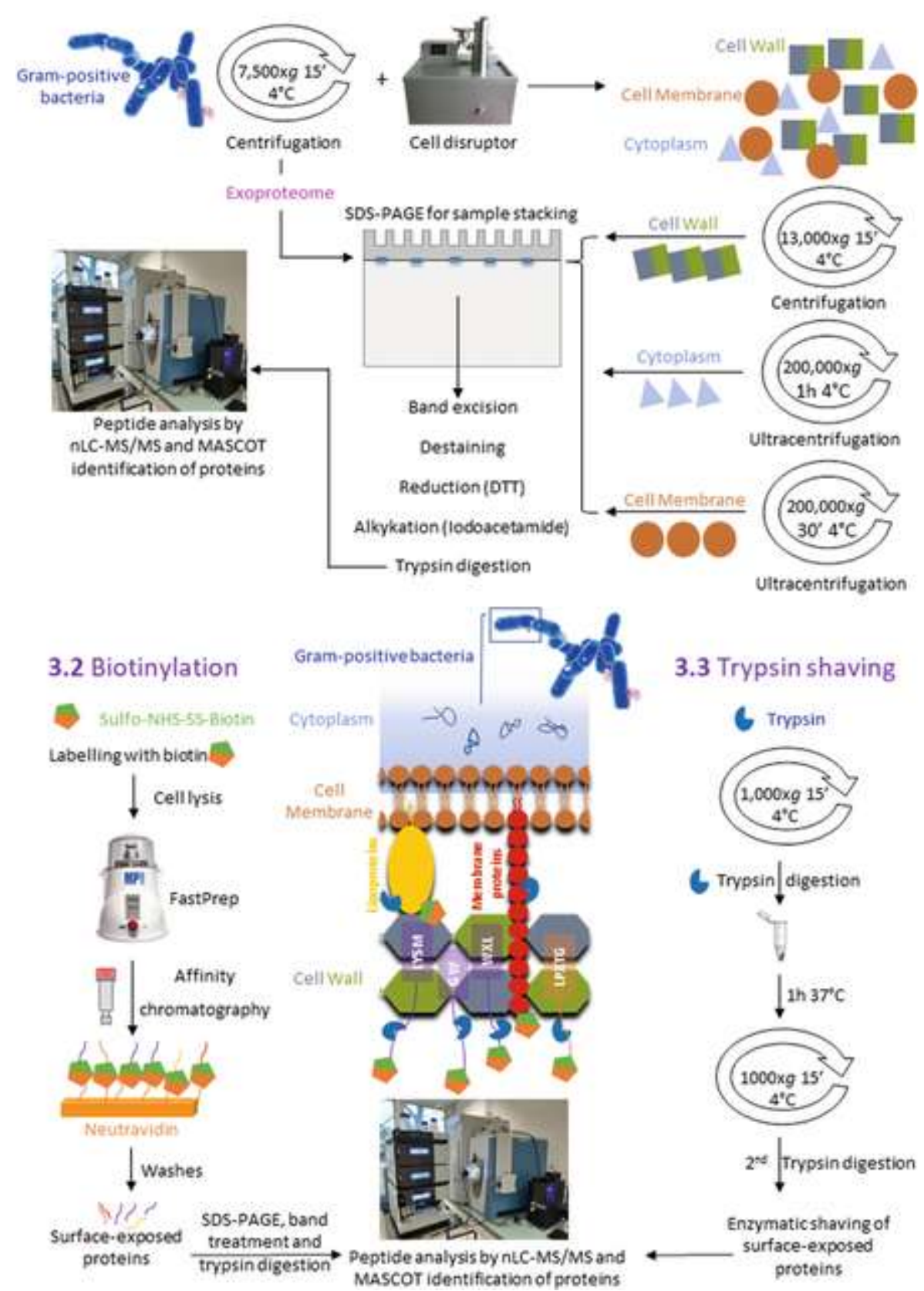

Fig. 1. Schematic workflows of the three methods for the preparation of $L$. monocytogenes subproteomes

\subsection{Cell Fractionation Approach}

\subsubsection{Cell Wall Proteins and Exoproteins}

1.The first step, whatever the subproteome of interest, consists in separating the bacterial cells from the culture supernatant. The volume of culture treated is dependent on the biomass yield, the efficiency of protein extraction, and the final quantity of proteins needed for the separation procedures. The procedures described hereafter have been used successfully in our laboratory in various studies on different strains of L. monocytogenes.

2.Harvest bacterial cells (usually $250 \mathrm{~mL}$ cultures) by centrifugation at $7500 \times \mathrm{g}$ for $15 \mathrm{~min}$ in a refrigerated centrifuge $\left(\right.$ at $\left.4{ }^{\circ} \mathrm{C}\right)$. 
3.Keep the bacterial pellet and carefully remove the supernatant and filter through a $0.2 \mu \mathrm{m}$ membrane either with syringe or bottle-top filter according to the volume of culture recovered (see Note 12). Maintain the supernatant in a cold environment with an ice bath.

4.Add $0.2 \mathrm{mM}$ PMSF and $0.2 \mathrm{mg} / \mathrm{mL} \mathrm{Na}$ deoxycholate. For $100 \mathrm{~mL}$ supernatant, add $1 \mathrm{~mL}$ of $20 \mathrm{mM}$ PMSF solution and $1 \mathrm{~mL}$ of Na deoxycholate solution. Incubate for $30 \mathrm{~min}$ on ice.

5.Precipitate proteins by adding 10\% TCA, and leave to incubate overnight at $4{ }^{\circ} \mathrm{C}$. For $100 \mathrm{~mL}$ supernatant, gradually add $25 \mathrm{~mL}$ TCA solution with manual agitation (see Note 13 ).

6.Centrifuge at $20,300 \times g$ for $30 \mathrm{~min}$ at $4{ }^{\circ} \mathrm{C}$. Eliminate the supernatant, and wash the pellet with ice-cold acetone (see Note 14). Repeat the washing step with ice-cold acetone at least twice, breaking up the pellet each time.

7.Solubilize the exoproteome protein sample into $100-500 \mu \mathrm{L}$ of SDS buffer, according to the concentration of proteins. Store this fraction enriched in membrane proteins at $-20{ }^{\circ} \mathrm{C}$.

8.Concerning the bacterial pellet, carefully wash it two times with TE buffer. Centrifuge at $7500 \times \mathrm{g}$ for $15 \mathrm{~min}$ at $4{ }^{\circ} \mathrm{C}$ between each washing procedure. Eliminate the supernatant.

9.Add $1 \mathrm{~mL}$ TE buffer and manually resuspend the pellet of bacterial cells.

10.Break bacterial cells with a cell disrupter (one shot cell disrupter, 1-8 mL, $2.7 \mathrm{kBar}$ max, Constant Systems Ltd., Daventry, UK) by applying $2.5 \mathrm{kBar}$ pressure for $10 \mathrm{~s}$. Repeat this procedure three times, and quickly place the solution in ice to avoid protein denaturation.

11.Centrifuge at $13,000 \times \mathrm{g}$ for $15 \mathrm{~min}$ at $4{ }^{\circ} \mathrm{C}$. Carefully aspirate the supernatant consisted of intracellular and membrane proteins. Place the supernatant in ice.

12. Store the pellet enriched in cell wall proteins at $-20{ }^{\circ} \mathrm{C}$.

\subsubsection{Intracellular Proteins}

1.Recover the supernatant of the previous section, and place it in an ultracentrifuge (UC) tube.

2.Precisely equilibrate the tubes at the $\mu \mathrm{g}$ by adding TE buffer drop by drop.

3.Ultracentrifuge the supernatant at $200,000 \times g$ for $1 \mathrm{~h} \mathrm{at} 4{ }^{\circ} \mathrm{C}$. Collect the supernatant corresponding to the intracellular proteome, store it at $-20{ }^{\circ} \mathrm{C}$, and keep the pellet containing cellular membranes.

\subsubsection{Membrane Proteins}

1.Resuspend the previous pellet in $40 \mathrm{mM}$ Tris buffer, and equilibrate the UC tube as previously described.

2.Ultracentrifuge at $200,000 \times \mathrm{g}$ for $30 \mathrm{~min}$ at $4{ }^{\circ} \mathrm{C}$. Eliminate the supernatant.

3. Recover the pellet containing cellular membranes from ultracentrifugation, wash with $40 \mathrm{mM}$ Tris buffer followed by ultracentrifugation $\left(200,000 \times \mathrm{g}, 30 \mathrm{~min}, 4{ }^{\circ} \mathrm{C}\right)$, and resuspend in $100 \mu \mathrm{L}$ of SDS buffer. Store this fraction enriched in membrane proteins at $-20{ }^{\circ} \mathrm{C}$.

\subsection{Biotinylation Approach}

\subsubsection{Biotin Labeling}

1.Harvest bacterial cells from the culture medium by centrifugation $(4000 \times g, 10 \mathrm{~min}$ at RT $)$.

2.Eliminate the supernatant and resuspend the pellet in $10 \mathrm{~mL}$ PMSF buffer.

3.Weigh $15 \mathrm{~mL}$ falcons prior to transferring the cell suspension. Centrifuge at $4000 \times \mathrm{g}$ for $10 \mathrm{~min}$ at RT and remove the supernatant.

4.Repeat this washing procedure three times as mentioned in the previous two points.

5.In order to define the amount of sulfo-NHS-SS-biotin needed for the extraction, weigh once again the falcon tubes, and calculate the humid cell mass obtained.

6.For each $100 \mathrm{mg}$ of humid cell mass, add $300 \mu \mathrm{L}$ of PMSF buffer. Carefully manually mix to avoid cell lysis. 
7.To label the surface exposed proteins, add $10 \mu \mathrm{L}$ of biotin buffer for each $100 \mu \mathrm{L}$ of bacterial solution. Let in contact in low agitation $(50 \mathrm{rpm})$ for $15 \mathrm{~min}$ at RT.

8.On the side perform control extractions, from the same batch of bacterial cultures, the same number of extractions, but this time without adding the biotin buffer at step 7 .

9.Eliminate the free biotin molecules by centrifugation at $4000 \times g$ during $5 \mathrm{~min}$ at RT and carefully eliminate the supernatant.

10.Stop the biotinylation by washing three times with $1.5 \mathrm{~mL}$ glycine buffer. At each step eliminate the supernatant.

11. Resuspend the biotinylated cells in $500 \mu \mathrm{L}$ of Triton buffer. In order to lyse the cells, transfer this solution to appropriated fast prep tubes with $200 \mathrm{mg}$ of glass beads. Mix $50 \%$ of $425-600 \mu \mathrm{m}$ beads and $50 \%$ of $<106 \mu \mathrm{m}$ beads. Leave the biotinylated cells and beads in contact for $10 \mathrm{~min}$.

12.For the lysis of biotinylated cells, use vigorous shaking $(6 \mathrm{~m} / \mathrm{s})$ in a FastPrep-24 cell breaker twice for $20 \mathrm{~s}$; protect the cells from overheating by placing the tubes in ice between repetitions and after the procedure is terminated.

13. Centrifuge at $20,000 \times g$ for $30 \mathrm{~min}$ at $4{ }^{\circ} \mathrm{C}$. Carefully aspirate the supernatant rich in biotinylated proteins, and store it at $4{ }^{\circ} \mathrm{C}$. Discard the pellet. At this stage, it is possible to continue the protocol the following day.

14.Quantify protein concentration with a Bradford protein assay (Bio-Rad protein assay), in theory, $12 \mathrm{mg}$ of proteins for each $500 \mu \mathrm{L}$ of volume.

\subsubsection{Purification of Biotinylated Proteins}

1.Recover labeled proteins by affinity chromatography in a monomeric neutravidin resin (Thermo Fisher Scientific), with gravity flow taking advantage of the chromatography affinity between neutravidin and biotin.

2.To prepare the neutravidin resin, place $0.8 \mathrm{~mL}$ Pierce ${ }^{\mathrm{TM}}$ centrifuge columns (Thermo Fisher Scientific) in $2 \mathrm{~mL}$ tubes, add $400 \mu \mathrm{L}$ of neutravidin, centrifuge at $500 \times g$ for $1 \mathrm{~min}$ at RT, and eliminate the supernatant consisted of stock solution (see Note 15).

3.Use NP-40 buffer to equilibrate and wash the resin three times with $400 \mu \mathrm{L}$. At each equilibration centrifuge at $500 \times g$ for $1 \mathrm{~min}$ at RT, and reject the supernatant.

4.Recover the lysate from the fridge, and centrifuge at $20,000 \times g$ for $30 \mathrm{~min}$ at RT. Carefully aspirate the supernatant to recover the lysate and reject the pellet.

5.Transfer $500 \mu \mathrm{L}$ lysate in the centrifuge column and close the $2 \mathrm{~mL}$ tube. Let the lysate be in contact with the neutravidin resin for $15 \mathrm{~min}$ at $150 \mathrm{rpm}$ and RT.

6.Place the column in a new $2 \mathrm{~mL}$ tube, and proceed with ten washes with NP-40 buffer and centrifugation at $500 \times \mathrm{g}$ for $1 \mathrm{~min}$. At each time eliminate the supernatant.

7.To elute the proteins trapped in the resin, add $600 \mu \mathrm{L}$ of reducing buffer for $15 \mathrm{~min}$ at RT. Break the low point of the columns, and place the columns in new $2 \mathrm{~mL}$ tubes.

8. To recover the elute, centrifuge at $500 \times \mathrm{g}$ for $1 \mathrm{~min}$ at $4{ }^{\circ} \mathrm{C}$. Repeat the elution procedure three times.

9.To concentrate the sample, transfer the elute in Amicon ${ }^{\circledast}$ ultra $0.5 \mathrm{~mL}$ filter units. Place the units inside $1.5 \mathrm{~mL}$ tubes. Centrifuge at $14,000 \times \mathrm{g}$ for $17 \mathrm{~min}$ at RT and empty the

tubes. Flip the filter unit, and centrifuge again at $14,000 \times g$ for 5 min at RT to obtain $100 \mu \mathrm{L}$ of concentrated elute. Store the elute at $-20{ }^{\circ} \mathrm{C}$.

\subsection{Shaving Approach}

1.Harvest bacterial cells from the culture

medium by low-speed centrifugation $\left(1000 \times g, 15 \mathrm{~min}, 4{ }^{\circ} \mathrm{C}\right)$ to minimize cell lysis (see Note 16). Gently wash the bacterial cell pellet twice with $2 \mathrm{~mL}$ of an ice-cold washing buffer containing $20 \mathrm{mM}$ Tris- $\mathrm{HCl}, \mathrm{pH} 7.4$, and $150 \mathrm{mM} \mathrm{NaCl}$.

2.Resuspend the cell pellet in $1 \mathrm{~mL}$ of shaving buffer containing $20 \mathrm{mM}$ Tris- $\mathrm{HCl}$, $\mathrm{pH} 7.6$, $150 \mathrm{mM} \mathrm{NaCl}, 10 \mathrm{mM} \mathrm{CaCl} \cdot \cdot 6 \mathrm{H}_{2} \mathrm{O}$, and $1 \mathrm{M} \mathrm{L}$-arabinose. 
3.Add the enzyme for cell surface shaving, generally trypsin $(0.5 \mu \mathrm{g} / \mathrm{mL})$, and incubate with gentle shaking at $37^{\circ} \mathrm{C}$ for $1 \mathrm{~h}$.

4.Centrifuge bacterial cells $\left(1000 \times g, 15 \mathrm{~min}, 4^{\circ} \mathrm{C}\right)$, and recover the supernatant containing the cleaved peptides. Filter the supernatant through a $0.2 \mu \mathrm{m}$ membrane.

5.Add $0.6 \mu \mathrm{g} / \mathrm{mL}$ trypsin, and incubate overnight at $37{ }^{\circ} \mathrm{C}$ to complete trypsic digestion of the peptides.

6.Purify and concentrate the extracted peptides on a Sep-Pak C18 Plus Light cartridge (Waters). Elute peptides with $500 \mu \mathrm{L}$ of a $80 \%$ ACN solution.

7.Evaporate the sample with a vacuum concentrator, and add $20 \mu \mathrm{L}$ solvent containing $\mathrm{H}_{2} \mathrm{O} / \mathrm{ACN}$ $(98 / 2)$ and $0.06 \%$ trifluoroacetic acid.

8. Separate the peptides obtained from the cell wall shaving by nano-liquid chromatography (nanoLC) on a PepMap C18 column (75 $\mu$ m diameter, $150 \mathrm{~mm}$ length, $100 \AA$ porosity) with a $4-70 \%$ gradient of solvent containing $\mathrm{ACN} / \mathrm{H}_{2} \mathrm{O}(95 / 5)$ and $0.5 \%$ formic acid for $30 \mathrm{~min}$ at a flow rate of $300 \mathrm{~nL} / \mathrm{min}$. The eluted peptides are analyzed by direct coupling of the nano-LC with an electrospray ionization ion-trap tandem mass spectrometer (ESI-IT-MS/MS) as for the previous approaches.

\subsection{SDS-Polyacrylamide Gel Electrophoresis (SDS-PAGE)}

\subsubsection{SDS-PAGE}

1.Perform SDS-PAGE and take advantage of the stacking gel in order to concentrate and improve the trypsin digestion of the protein extraction samples from the exoproteins, cell wall, membrane, and intracellular fractions and the biotin-labeled protein samples.

2.Mark the upper part of the glass plates. Mark at $5 \mathrm{~mm}$ and at $35 \mathrm{~mm}$ to define the beginning of the stacking gel and the resolving gel, respectively.

3.Prepare and load the $12.5 \%$ acrylamide solution for the resolving gel until the $35 \mathrm{~mm}$ mark within assembled glass plates placed in a casting chamber. Just after, add $2 \mathrm{~mL}$ of water on top of the gel; due to density differences, the water will stay on top and will promote the flatting of the gel. Wait between 45 and 60 min for the polymerization of the resolving gel. In between prepare the solution for the staking gel.

4.Absorb water with Whatman ${ }^{\circledast}$ qualitative filter paper, and load the $4 \%$ acrylamide solution for the staking gel until the $5 \mathrm{~mm}$ mark within the assembled glass plates. Promptly and carefully place the chosen well plate to avoid the formation of air bubbles. Allow the polymerization of the gel to happen for 30-45 min. In between prepare the samples to be loaded in the gel. Add one volume of Laemmli buffer $2 \times$ to one volume of sample, and place this mix at $95{ }^{\circ} \mathrm{C}$ for $5 \mathrm{~min}$.

5.After carefully removing the well plate, wash the wells with SDS-PAGE buffer, and load with a Hamilton syringe $5-10 \mu \mathrm{L}$ of samples.

6.Add $1 \times$ SDS-PAGE running buffer to the lower chamber of the electrophoresis apparatus, and then move the gels inside, and add running buffer in the upper chamber to cover the top of the gels. Place the lid onto the electrophoresis apparatus to secure the device and allow electric current application.

7.Run the gels at $15 \mathrm{~mA}$ constant per gel for more or less 40 min depending until the bromophenol blue dye and all the samples enters into the upper part of the resolving gel.

\subsubsection{Protein Staining and Band Treatment After Excision}

1.After electrophoresis, proteins are stained according to procedure described by Neuhoff et al. [23]. Perform all steps with gentle agitation on an orbital or back and forth shaker. Fix the gels with three successive baths of $30 \mathrm{~min}$ each in the fixing solution freshly prepared (about $300 \mathrm{~mL}$ per gel).

2.Rinse $3 \times 20$ min with washing solution.

3.Incubate the gels for $30 \mathrm{~min}$ in the equilibration solution, freshly prepared. 
4.Add 1\% (v/v) of the Coomassie brilliant blue G-250 solution ( $3 \mathrm{~mL}$ for $300 \mathrm{~mL}$ of equilibration solution) to the equilibration solution. Let the stain proceed for $24-72 \mathrm{~h}$.

5.If necessary, destain the background with water.

6.The stained proteins can be more easily visualized by placing the gel on a light table. Proceed to discard the stacking gel, and cut, with the help of a scalpel, the first half centimeter of resolving gel containing the protein band. Place the gel bands in properly labeled $1.5 \mathrm{~mL}$ tubes.

7.Prior to mass spectrometry analysis of the protein extracts, it is essential to remove any leftovers of dye, reduce disulfide bonds and alkylate cysteines.

8.Add $1 \mathrm{~mL}$ of the first destaining solution ( $25 \mathrm{mM}$ ammonium bicarbonate and $5 \% \mathrm{ACN})$ for $30 \mathrm{~min}$ in strong vortex agitation, followed by two times the second destaining solution $(25 \mathrm{mM}$ ammonium bicarbonate and 50\% ACN). Discard the solutions at each time.

9.Add $100 \mu \mathrm{L}$ reduction solution for $1 \mathrm{~h}$ at $55^{\circ} \mathrm{C}$. Discard the solution.

10.Add $100 \mu \mathrm{L}$ alkylation solution for $20 \mathrm{~min}$ in the dark.

11.To turn the protein $\mathrm{pH}$ back to alkaline, add once again $1 \mathrm{~mL}$ of the second destaining solution for 20 min with vortex agitation. Test the $\mathrm{pH}$, and if not alkaline, perform this step once again.

12.Prior to trypsin protein digestion, dehydrate the gel bands in $100 \% \mathrm{ACN}$ solution for $15 \mathrm{~min}$ in vortex agitation.

13. Hydrolyze proteins overnight at $37{ }^{\circ} \mathrm{C}$ using $48 \mu \mathrm{L}$ of trypsin solution per band.

14.Extract peptides from the gel bands in an ultrasonic field during 10 min with $38.4 \mu \mathrm{L}$ of $100 \%$ ACN representing $80 \%$ of digestion volume.

15.Prior to nano-LC-MS/MS analysis, transfer supernatants in Eppendorf vials, and dry them using a SpeedVac for $45 \mathrm{~min}$, and add $40 \mu \mathrm{L}$ of equilibration solution $\left(\mathrm{H}_{2} \mathrm{O} /\right.$ Trifluoroacetic Acid $-99.95 / 0.05)$.

16. Samples are ready to be analyzed by nano-LC ESI-IT-MS/MS (shotgun analysis).

\section{Notes}

1.PMSF is an irreversible inhibitor of serine proteases and some cysteine proteases. It is a cytotoxic chemical which should be handled only inside a fume hood. Stock solution is prepared in ethanol due to its rapid degradation in water. Other protease inhibitors with similar specificity but less toxic than PMSF can be used such as AEBSF (4-(2-aminoethyl)benzenesulfonyl fluoride hydrochloride), marketed under the name of Pefabloc.

2.Sodium deoxycholate is an ionic detergent commonly used for disruption and dissociation of protein interactions. Here, it is used as a co-precipitant helping protein precipitation after addition of the stronger acid TCA.

3.TCA is a corrosive chemical; handle with care in a fume hood. The product is hygroscopic; keep it in a cool, dry, and ventilated area in a tightly sealed container.

4.The powder is difficult to weigh and solubilize. To facilitate its solubilization, pour one or two drops of DMSO into the biotin, and stir to obtain a paste; then add the rest of the PBS volume. Do not prepare stock solution, because in time the NHS-ester group hydrolyzes. Make solution as and when manipulation time.

5.Triton is a viscous product that is hard to dissolve; prepare this buffer before the manipulation.

6.Add the PBS at RT; otherwise the NP-40 does not dissolve.

7.Wear a mask and work under a fume hood when weighing SDS.

8.DTT (dithiothreitol) is a negatively charged reducing agent, allowing the reduction and preventing oxidative crosslinking of disulfide bonds.

9.Ammonium persulfate is a strong oxidizing agent used along with TEMED to catalyze the polymerization of acrylamide. It is better to prepare this solution freshly each time.

10.TEMED is a free radical stabilizer. Storing at $4{ }^{\circ} \mathrm{C}$ reduces its unpleasant smell. 
11.Iodoacetamide is an alkylating agent that binds covalently with the thiol group of cysteine and thus avoids the reformation of disulfide bonds. BPB is used here to view the ion front (migration front) with which it migrates during SDS-PAGE.

12.If the volume of culture recovered is too important, it is recommended to concentrate by filtration with centrifugation at $3500 \times \mathrm{g}$ in a refrigerated centrifuge $\left(4{ }^{\circ} \mathrm{C}\right)$ through a polyethersulfone membrane with a molecular range cutoff at $5 \mathrm{kDa}$.

13.TCA is an efficient protein precipitant particularly suitable for large volumes; it allows instantaneous inactivation and precipitation of all the proteins including proteases, while excluding small ionic molecules (salts, nucleotides, phospholipids, etc.) and polysaccharides. Other precipitation procedures can be used with ice-cold acetone (at least three volumes for one volume of sample) or with a solution of TCA in acetone (final concentration of $10 \%$ TCA in the sample).

14.Acetone is an organic solvent commonly used to precipitate proteins. Use acetone-resistant centrifuge tubes and a glass pipette to add it. It is necessary to wash the pellet extensively (at least three times) with acetone $(10-15 \mathrm{~mL}$ for an initial volume of $100 \mathrm{~mL}$ culture medium) to remove residual TCA which can acidify the sample and may cause degradation of proteins. The $\mathrm{pH}$ can be controlled by placing a drop on a $\mathrm{pH}$ indicator strip.

15.Take precautions while pipetting close to the column resin to avoid piercing it, and vigorously agitate the neutravidin agarose before pipetting.

16.It is essential to avoid/limit bacterial cell lysis during shaving. Consequently, the parameters for shaving may be different according to the growth parameters $\left(T^{\circ} \mathrm{C}\right.$, culture medium, growth phase, etc.) of bacterial cells making them more or less susceptible to lysis. Cell lysis can be checked by the presence of nucleic acids in the culture medium.

\section{Acknowledgments}

The author thanks J. Esbelin and I. Chafsey for their involvement in the development of proteomic approaches. The author also thanks D. Viala and C. Chambon, engineers on the Metabolomic and Proteomic Exploration Facility (PFEMcp) from INRAE Saint-GenèsChampanelle (France), who bring their skills to perform all our analysis by mass spectrometry. Tiago Santos was seconded by List_MAPS project, which received funding from the European Union's Horizon 2020 research and innovation program under the Marie Sklodowska Curie grant agreement no. 641984 .

\section{References}

1.Desvaux M, Hébraud M, Talon R, Henderson IR (2009) Secretion and subcellular localizations of bacterial proteins: a semantic awareness issue. Trends Microbiol 17:139-145

2.Desvaux M, Candela T, Serror P (2018) Surfaceome and proteosurfaceome in parietal monoderm bacteria: focus on protein cell-surface display. Front Microbiol 9:100

3.Cabanes D, Dehoux P, Dussurget O, Frangeul L, Cossart P (2002) Surface proteins and the pathogenic potential of Listeria monocytogenes. Trends Microbiol 10:238-245

4.Desvaux M, Dumas E, Chafsey I, Hébraud M (2006) Protein cell surface display in Grampositive bacteria: from single protein to macromolecular protein structure. FEMS Microbiol Lett 256:1-15

5.Bierne H, Cossard P (2007) Listeria monocytogenes surface proteins: from genome predictions to function. Microbiol Mol Biol Rev 71:377-397

6.Dramsi S, Bierne H (2017) Spatial organization of cell wall-anchored proteins at the surface of Gram-positive bacteria. Curr Top Microbiol Immunol 404:177-201

7.Ghosh BK, Carroll KK (1968) Isolation, composition, and structure of membrane of Listeria monocytogenes. J Bacteriol 95:688-699

8.Hébraud M, Desvaux M (2008) Chapter 12: Analysis of cell envelope proteins. In: Liu D (ed) Handbook of Listeria monocytogenes. CRC Press, Taylor and Francis Group, Boca Raton, FL, pp 359-393 
9.Desvaux M, Hébraud M (2006) The protein secretion systems in Listeria: inside out bacterial virulence. FEMS Microbiol Rev 30:774-780

10.Desvaux M, Hébraud M (2009) Chapter 14: Listeria monocytogenes. In: Wooldridge K (ed) Bacterial secreted proteins: secretory mechanisms and role in pathogenesis. Caister Academic Press, Norwich, pp 313-345

11.Desvaux M, Dumas E, Chafsey I, Chambon C, Hébraud M (2010) Comprehensive appraisal of the extracellular proteins from a monoderm bacterium: theoretical and empirical exoproteomes of Listeria monocytogenes EGD-e by secretomics. J Proteome Res 9:5076-5092

12.Hébraud M (2014) Analysis of Listeria monocytogenes subproteomes. Methods Mol Biol 1157:109-128

13. Solis N, Cordwell SJ (2011) Current methodologies for proteomics of bacterial surfaceexposed and cell envelope proteins. Proteomics 11:3169-3189

14.Olaya-Abril A, Jiménez-Munguia I, Gómez-Gascón L, Rodríguez-Ortega MJ (2012) Another turn of the screw in shaving Gram-positive bacteria: optimization of proteomics surface protein identification in Streptococcus pneumoniae. J Proteomics 75:3733-3746

15.Rodríguez-Ortega MJ (2018) "Shaving" live bacterial cells with proteases for proteomic analysis of surface proteins. Methods Mol Biol 1722:21-29

16.Sievers S (2018) Membrane proteomics in Gram-positive bacteria: two complementary approaches to target the hydrophobic species of proteins. Methods Mol Biol 1841:21-33

17. Schaumburg J, Diekmann O, Hagendorff P, Bergmann S, Rohde M, Hammerschmidt S, Jänsch L, Wehland J, Kärst U (2004) The cell wall subproteome of Listeria monocytogenes. Proteomics 4:2991-3006

18.Calvo E, Pucciarelli G, Bierne H, Cossart P, Albar JP, Garcia-del Portillo F (2005) Analysis of the Listeria monocytogenes cell wall proteome by two-dimensional nanoliquid chromatography coupled to mass spectrometry. Proteomics 5:433-443

19.Bonn F, Maaß S, van Dijl JM (2018) Enrichment of cell surface-associated in Gram-positive bacteria by biotinylation or trypsin shaving for mass spectrometry analysis. Methods Mol Biol 1841:35-43

20.Tiong HK, Hartson SD, Muriana PM (2015) Comparison of five methods for direct extraction of surface proteins from Listeria monocytogenes for proteomic analysis by orbitrap mass spectrometry. J Microbiol Methods 110:54-60

21.Tiong HK, Hartson SD, Muriana PM (2016) Comparison of surface proteomes of adherence variants of Listeria monocytogenes using LC-MS/MS for identification of potential surface adhesins. Pathogens 5:54-60

22.Esbelin J, Santos T, Ribière C, Desvaux M, Viala D, Chambon C, Hébraud M (2018) Comparison of three methods for cell surface proteome extraction of Listeria monocytogenes biofilms. OMICS 22:779-787

23. Neuhoff V, Arold N, Taube D, Ehrhardt W (1988) Improved staining of proteins in polyacrylamide gels including isoelectric focusing gels with clear background at nanogram sensitivity using Coomassie Brilliant Blue G-250 and R-250. Electrophoresis 9:255-262 